\title{
The Benefits of Unemployment Insurance Fund in Jordan
}

\author{
Jihad A. Abu Al Sondos (PhD, Professor) \\ Faculty of Business / Economics Department, \\ Al Balqa Applied University,Al Salt, Jordan
}

Doi:10.19044/esj.2019.v15n4p333 ～$\underline{\text { URL:http://dx.doi.org/10.19044/esj.2019.v15n4p333 }}$

\begin{abstract}
This paper focuses on identifying the benefits of the Unemployment Insurance Fund (UIF) in Jordan, and how it achieves a direct and indirect social protection for unemployed insured persons through enhancing job security, reducing unemployment rates, and encouraging graduates to recruit on jobs that are available in many different private sectors.

The research employs a descriptive statistical method by analysing the collected annual data that is issued by the Social Security Corporation (SSC), which is related to a cumulated size of beneficiaries from the UIF and total compensation paid for insured persons within the same period. The data pertaining to these persons comprises of their distribution by gender, age, geographical area, wages, unemployment time, and economic activities.

In this research, it is recommended to extend a number of beneficiaries from the UIF by including more unemployed persons who subscribe at the SSC, and who increase their ratio estimation of the monthly compensation. Additionally, the research enhances the corporative efforts by involving international, regional, and local organisations that aim at reducing unemployment rates by hosting an effective debate with all of them.
\end{abstract}

Keywords: UIF, beneficiaries, insured persons, compensation payments, unemployment

\section{Introduction}

Jordan has been suffering from rising unemployment rates, particularly, during the past two decades where the total number of Jordanian labour force reached 1.818 million, (1.419 and 0.399 million of unemployed Jordanian males and Jordanian females, respectively). The number of unemployed Jordanians reached 0.333 million, (Ministry of Labour, 2018). Accordingly, the unemployment rate reached $18.1 \%$ (15.8\% of Jordanian males and $27.2 \%$ of Jordanian females) (Department of Statistics, 2018). 
The unemployment rate based on the education level is shown to be the highest among Jordanians holding degree and higher education levels reaching $23.9 \%$ compared to those Jordanians who are holding an intermediate diploma level of $16.8 \%$, secondary level of $11.6 \%$, less than secondary level of $17.5 \%$, and illiterate level of $11.6 \%$ (Ibid, 2018). Jordanian workers with lower educational level face a robust competition from foreign workers that are being preferred by many employers (Sondos \& Kharmeh, 2010).

However, the highest unemployment rate by age is recorded into two age groups; $15-19$ years old at $37.8 \%$ and $20-24$ years old at $34.5 \%$. Furthermore, the distribution of unemployed persons by the governorate is recorded in Amman at $40.3 \%, 17.2 \%$ in Irbid, $14.2 \%$ in Zarqa, and the lowest percentage is recorded in Aqaba at 1.1\% (Department of Statistics, 2018).

The Social Security Corporation (SSC) provides some insurance services for elderly people, sickness, disability, death, work injury, maternity, and unemployment insurance. Other protection services include health care, prevention of pollution hazards, and working difficulties (Social Security Corporation, 2014).

Nonetheless, the ratio of insured persons that benefit from social insurance services in comparison with the total number of subscribers for the SSC is still low. Consequently, insurance services are important when including further workers in informal labour sectors who are already subscribed at the SSC, which allows them to benefit from the Unemployment Insurance Fund (UIF). The main role of UIF is to continuously provide their subscribers with monthly incomes after they are likely to resign from their involved or dismissed jobs.

Additionally, the UIF is considered as one of the most important social insurances, which improves life stability for a wider range of workers within private sectors. Therefore, the monthly deductions for UIFs are considered as saving and investment accounts for insured workers who receive their savings and investment returns from the UIF after handling their insurance reliabilities with the SSC.

Therefore, the theoretical framework of this research is adapted based on the following steps:

\section{- Research Problem}

The issue that is still being addressed by the UIF represents a low percentage of Jordanian workers who are already subscribed at the SSC and who are working in formal private economic sectors. Despite the fact that these workers are not benefiting from the UIF in public and informal private economic sectors, most of them are subscribed at the SSC representing more than $60 \%$ of the total workers in the labour market in Jordan (Social Security Corporation, 2017). 
Moreover, the UIF provides monthly compensations for unemployed persons who work in formal private sectors and who are resigned or dismissed from their jobs. Meanwhile, private sectors in both formal and informal economics' sides witness fluctuations and are regularly characterised by job instability, particularly, in small-medium sized corporations. Subsequently, subscribers are entitled to compensation from the UIF during the period of temporary unemployment when resigning from their involved or dismissed jobs. In addition, subscribers can benefit from the UIF for up to three times during their career course.

\section{- Research Objectives}

The objectives of the research comprises of the following:

1. Developing the applied mechanism of the UIF is based on the instructions and conditions of the benefit.

2. Analysing the characteristics of beneficiaries from the UIF according to their distribution by gender, age, governorate, monthly wage, unemployment duration, and economic activities.

3. Illustrating compensation payments from the UIF for beneficiaries according to their length of insured time.

4. Explaining the role of the UIF in reducing unemployment rates and in encouraging fresh graduates to seek potential vacancies that are advertised in private sectors.

5. Identifying a possible method in which the UIF can incorporate training and rehabilitation centres to implement fitted trainings and developing programs for unemployed Jordanians.

\section{- Research Motivation}

The motivation of this research includes:

1. Clarifying the impact of the UIF through socio-economic characteristics of beneficiaries.

2. Contributing on activating the role of the UIF.

3. Recommending effective policies to decrease the unemployment rate, improve living standards of unemployed Jordanians, and make them subject of being adopted by planners, decision-makers, and stakeholders.

4. Using this research as a useful reference for students and researchers when the period of applying the UIF is short.

\section{- Research Methodology}

\section{Data Sources}

The research uses the data and information regarding the characteristics of unemployed Jordanian persons who are benefiting from the UIF. This 
is carried out by the Jordanian SSC where the start of this insurance program is from 2011 up to the end of 2017.

\section{Analytical Methods}

The research uses an annual data that is issued by the SSC for the entire socio-economic variables that are related to the unemployed Jordanians who are benefiting from the UIF. Additionally, descriptive statistical analysis of data collection are employed. The estimated ratios and averages pertaining to the main analytical and figured results include:

- The characteristics of beneficiaries from the UIF according to their distribution that consists of gender, age, governorate, monthly wage, unemployment duration, and economic activities.

- The total contributions of firms and insured persons in private sectors who have switched along to the UIF at a monthly level.

- The total insured persons and compensation payments for them from the UIF for beneficiaries according to the length of the insured time.

- Reviewing the literature aspects of the unemployment insurance.

- Recognising the impact of the UIF on the labour market reality, life of unemployed workers, society, and economy situation.

\section{Concept and the Role of Unemployment Insurance}

When unemployment rates increase persistently, it is likely to be extended to a condition where more workers use their unemployment insurance benefits. Hence, further workers face unemployment in which their potential duration of unemployment insurance benefits is exceeded regardless of the extended spells of unemployment that occur when job separation emerges (Christopher \& Stephen, 1997).

Unemployment insurance is defined as an economic stabilisation that provides a safety life and paying compensation for unemployed workers who were dismissed from their jobs. Other definition of unemployment insurance can be the temporary incomes for workers who are partially unemployed, who lose their current jobs, who are still looking for new job opportunities, or who are enrolled in rehabilitative training programs to return back to previous or new jobs (Service Canada, 2010).

The UIF also helps to stabilise the national economy during recessions via paying monthly compensation for unemployed persons. However, this can also help to improve the social life level and reduce health problems among unemployed persons (Enchautegui, 2012). Most of the advanced and developing economies respond to solve unstable problems on the social life of unemployed persons by providing unemployment insurance program. In most cases, this program is provided by public sectors by following several 
provisions that are designed to eliminate what is seen as possible abuses of implementing the program (Martin Neil Baily, 1978).

The UIF covers unemployed job seekers in order to allow retaining partial benefits during the periods of insufficient part-time work. This is done such that small temporary part-time jobs can probably provide access to useful information regarding vacancies. At the same time, such jobs are probably used by employers as a previous experience when hiring unemployed persons (Anna Godøy \& Knut Røed, 2014).

Unemployment insurance is a key component of social insurance in modern welfare countries where microeconomic theory develops unemployment insurance based on an optimal way that is effectively understood. Although it helps workers to smoothly consume the time they are unemployed, it also increases unemployment by discouraging the job search (Camille Landais et al., 2010).

Unemployment insurance fund is distinguished from other social insurances since it provides job security for workers, particularly those within private sectors. It makes the work environment more sustainable and stable in local labour market. The UIF is a key to reform, and is able to reduce a scale risk and dampen asymmetric shocks by providing an insurance income to households who are most vulnerable. It also improves the economic resilience through a sustainable way and strengthens the social dimension policy-making (Mathias Dolls et al., 2014).

A permanent increase of the labour productivity has the same effect on hiring a permanent decrease in the UIF according to the same absolute amount, while a temporary rise in the labour productivity has a smaller impact (Costain $\&$ Reiter, 2006). The high number of beneficiaries of unemployment insurance means that there is no stability in the employability of labour force, particularly when the turnover rate of a labour becomes higher.

The unemployment insurance fund contributes in bridging the gap between the previous jobs and obtaining new jobs. Therefore, this covers insured persons in the SSC, who work in private sectors and who have lost their jobs. This type of insurance is an extremely positive service for regulating the movement of workers through entry and by exiting to labour markets. Additionally, this type protects the labour force from fluctuations related to economic cycles and its reflections on labour market. Increasing unemployment insurance payments is not similar to the increment of the value of leisure while unemployed. Nonetheless, this increment automatically leads to higher negotiated wages. If a worker has the entire bargaining power, then all firms would become worsened (Coles \& Masters, 2007).

Payments are made through unemployment insurance to unemployed persons who meet the eligibility standards. In order to be primarily qualified, the worker should possess the least level of previous employments and/or 
previous wages and be detached from work based on particular circumstances. A person is still devoted to labour forces where the popular descriptor of this condition is being capable to work and it does exist accordingly. Payments of unemployment Insurance are occasionally being made, however, with limited and possible period of time. Within the majority of unemployment insurance programs, the periodic payment level is completely connected to the past earnings' level where possible payment period is accordingly connected to a previous work experience (Vroman \& Brusentsev, 2005).

In some cases, a worker may be eligible for benefit based on quitting a job for an effective reason. Persons who voluntarily leave their work must meet an effective cause that is explicitly restricted to reasons that are connected with a particular work, attributable to the employer or involving fault on the part of the employer (Julie et al., 2017). The UIF also serves as a wide range of middle-income employees since it provides them with a source of income if they are forced to leave the labour market for economic reasons such as a recession or projects failure. In this case, the employer is forced to dismiss employees from their jobs.

The UI program is supposed to encourage employers to create less unemployment (The Legal Aid Society-Employment Law Centre, 2010). However, increasing its benefits may increase job finding among unemployed individuals through forward viewing and through recognising that future employment spells carry layoff risks (Bennmarker et al., 2005).

Furthermore, there exist four reasons why workers are unemployed as they may have left their previous jobs voluntarily (i.e. voluntary quits). Also, they may have lost their jobs since they were resigned or terminated, they may have not worked in the past years, and they may be workers who have never worked (Monica Townson \& Kevin Hayes, 2007).

It is necessary to choose an optimal unemployment insurance policy. Additionally, policymakers have to weigh between their costs and benefits as extending benefits may dull the incentives for unemployed workers to exert effort in searching for another possible job leading to increase unemployment that is so-called the 'moral-hazard effect' (The Council of Economic Advisers and the Department of Labour, 2013).

Policymakers have to take more cautious inquiry into the determinants of unemployment benefits prior to producing any macroeconomic policy actions. Workers desire enough insurance against unemployment, but higher benefits require higher taxes that cause budget constraint and that brings higher unemployment which causes incentive constraint (Rafael et al., 2002). Every worker faces a high unemployment risk, which may further select a comprehensive insurance coverage. Nonetheless, it is not considered to be the best policy to satisfy the desires of unemployed individuals whose fears 
remained for a long time waiting for any possible job (Camille Landais et al., 2017).

Consequently, the actions of unemployment compensation concentrate on a client population that possess an increased proportion of turnover. When involving beneficial applications, administrative judgments can be taken into effect with regards to an initial eligibility and continuity in providing eligibility for claimants who obtain a first payment (Vroman \& Brusentsev, 2005). The UIF must provide assistance to unemployed workers by implementing two basic roles: (1) assisting in the administration pertaining to the working assessment, and by (2) giving the main labour exchange and job search help to unemployed insurance claimants (Christopher \& Stephen, 1997).

Unemployment compensation program very often enables unemployed persons to exit the labour market via benefits by discouraging them from continued job seeking. Consequently, the administration has to support some particular reforms of the unemployment insurance program and must test further new significant strategies in order to help enabling unemployed workers to return back to work. There is a variety of reforms of the UIF program that can help workers to seek jobs quicker than ever by encouraging struggling employers to reduce the number of hours for workers rather than laying them off. Furthermore, such reforms allow unemployed persons who are receiving benefits to start running their own businesses by supporting and expanding several types of entrepreneurship programs (The Council of Economic Advisers and the Department of Labor, 2013).

If there is an appropriate unemployment insurance system, dismissed workers can retain their skills until they find a suitable job that makes use of their capabilities. If their skills are out-dated, they can afford being trained to obtain new skills that suit required professional competences. In either case, unemployment insurance is helpful for unemployed persons in developing their skills and improving the efficiency of the local labour market (Kamimura, 2010).

The prolonged benefits of unemployment insurance must be supported with less payroll taxes or using governmental incomes. Financing unemployment insurance benefits generates economic inducements for many organisations to act in manners that aim at minimising temporary layoffs. In addition, it bounds the extent to which employers within cyclically and occasional sensitive organisations are being supported by many employers through further constant organisations (Christopher \& Stephen, 1997).

Additionally, an inducement is created by a payroll tax cap for employers in order to allocate more working hours (i.e. extra working hours than should be) to their available work force instead of hiring extra workers for a job. Whether prolonged benefits are funded by a payroll tax or by general incomes, 
the action relies on problems related to tax equity. Financing the unemployment insurance based on a payroll tax is partially transported to workers based on fewer wages and to consumers based on greater costs (Christopher \& Stephen, 1997).

The unemployment insurance fund in Jordan aims at alleviating the socialeconomic implications of the unemployed persons and it also helps them to overcome critical periods. Subsequently, insured persons have to take the following into considerations (The Official Newspaper no. 5329, 2015):

- To meet the conditions of benefiting from the unemployment insurance fund, which are overlooked by some persons, the most important condition is to ensure that workers would not perform their job based on their own decision in cases of dismissal. Also, they should be able and willing to work; should continuously seek possible jobs; and they should be given consent to work in current wages within the labour market.

- There is a commitment of visiting the SSC for filling out the unemployment insurance form if workers are dismissed from their job, unless they are dismissed from a job that does not refer to disciplinary grounds. Additionally, they must agree to be enrolled in a required training and pass it successfully, and not work for their own business or any particular occupations.

The law of the SSC obliges all employers in private economic sectors to subscribe to an unemployment insurance program to ensure that workers could obtain compensation after dismissal. This action subjects them to pay a $1.5 \%$ deduction of monthly wages to the UIF, which deducts from an employer $0.5 \%$ and a worker $1 \%$. Also, the unemployment insurance fund has to compensate insured persons based on the percentage of the last monthly deductible wages for the SSC, which is $75 \%$ for the first month, $65 \%$ for the second month, $55 \%$ for the third month, and $45 \%$ for the remaining three months (i.e. the fourth, fifth, and sixth month). In all cases, the maximum monthly compensation does not exceed 500 Jordanian dinars per month where it is annually being linked to the inflation rate (Social Security Corporation, 2014).

The UIF has to play an effective role by directing those who are not working in the field of their expertise towards specialised training centres to rehabilitate their skills and knowledge and to facilitate seeking other current jobs. Each insured person deserves compensation due to their missed job, since holding an SSC for a minimum of 36 months allows them to benefit from unemployment insurance fund.

The other condition refers to the age of subscribers, which is lower than 60 years for male persons and 55 years for female persons. Every unemployed person can obtain monthly compensation from the UIF depending on the following conditions (Ibid, 2014):

- Three months, if the number of subscriptions is lower than 180 months. 
- Six months, if the number of subscriptions is 180 months or more.

According to the above mentioned conditions, the unemployment insurance fund contributes to achieving two main objectives, which comprises of the following:

1. The provision of alternative, partial, and temporary incomes to workers who are forced to involuntarily leave their jobs.

2. Achieving job stability, particularly, during the cycles of economic recession.

\section{Discussion and Results}

\section{- Characteristics of Beneficiaries}

The total insured persons at the SSC reached 1,285,168 subscribers in 2017 and was distributed by $87.4 \%$ Jordanians and $12.6 \%$ non-Jordanians, representing $72.1 \%$ male Jordanians and $27.9 \%$ female Jordanians. Moreover, $41.9 \%$ of insured Jordanians are working in public sectors compared to those Jordanians who are working in private sectors and they represent $51.1 \%$. Further, 96.4\% of insured non-Jordanians are working in private sectors compared to those who are working in public sector and they represent 3.3\%. The remaining $7 \%$ of insured persons are working in the Non-Governmental Organisations (NGOs), international institutions, and own businesses (Social Security Corporation, 2012-2017).

The total beneficiaries of unemployed persons from the UIF increased from 4,231 persons in 2012 to 8,644 persons in 2014 and reached 13,718 persons in 2017 (ibid, 2012-2017) (Figure 1).

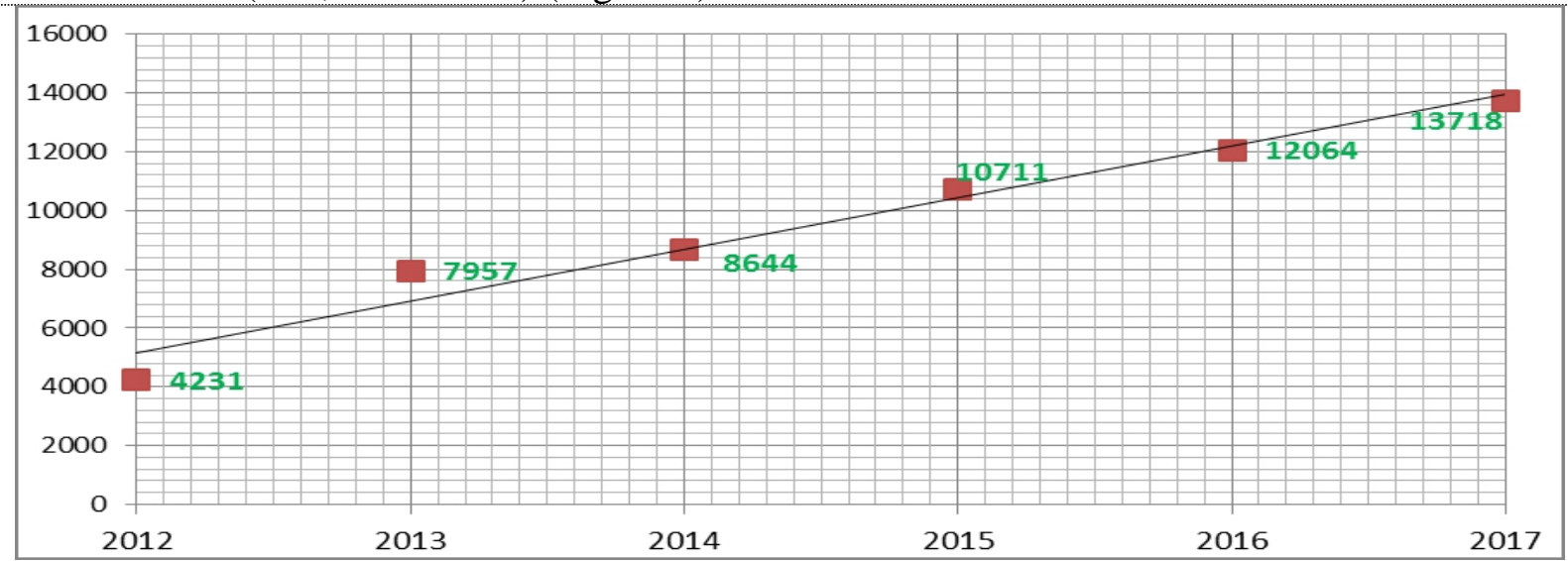

Figure 1. The trend of total beneficiaries from the UIF during 2012-2017

Meanwhile, the trend percentages of beneficiaries from the UIF by gender are observed to have increased in female Jordanians (14.9\%) compared to male Jordanians $(85.1 \%$ ) during the period of 2012. A couple of years later, there was an increment of $16.8 \%$ of female Jordanians and $83.2 \%$ of male 
Jordanians in 2014. In 2017, it reached $21.6 \%$ of female Jordanians and 78.4\% of male Jordanians (see Figure 2).

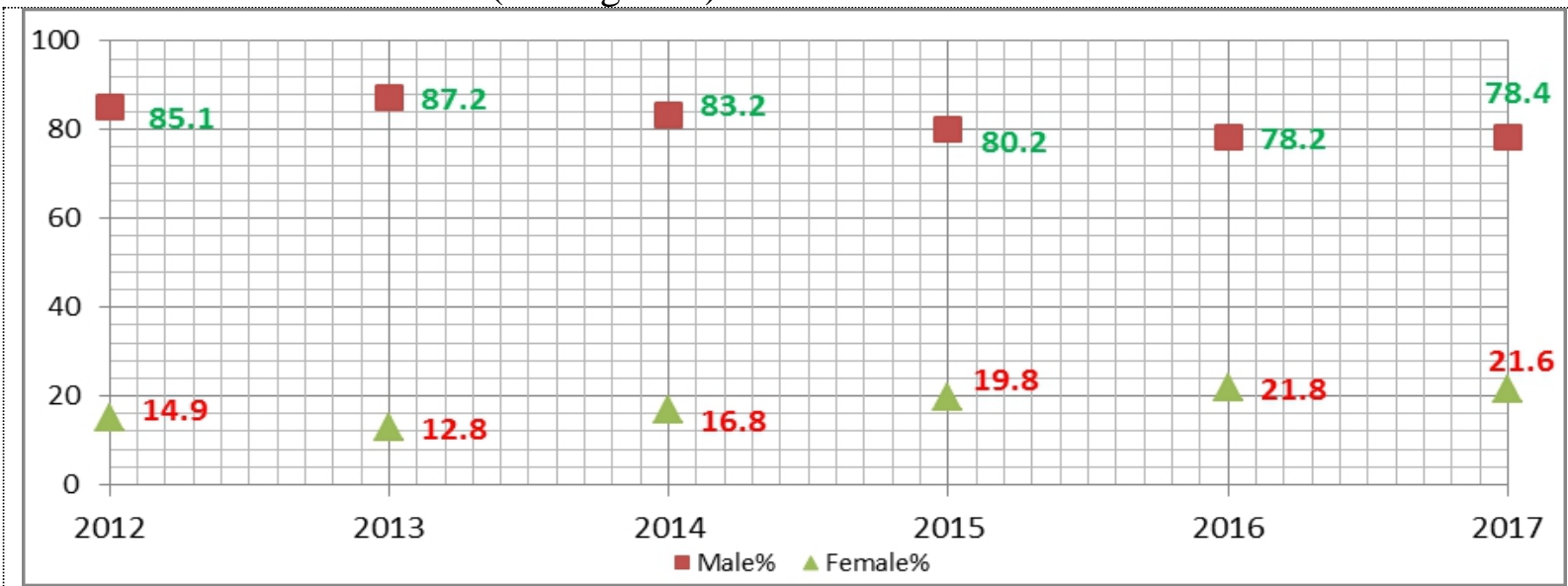

Figure 2. The trend percentages of beneficiaries from the UIF by gender during 2012-2017

The total accumulation of monthly contributions paid by all insured persons to the UIF increased from 44.784 million Jordanian dinars in 2012 to 55.698 million Jordanian dinars in 2015 and it later increased to 62.623 million Jordanian dinars in 2017. On the contrary, the total amount of compensation payments by the UIF to beneficiaries increased from 3.863 million Jordanian dinars in 2012 to 11.806 million Jordanian dinars in 2015 and it later increased to 16.922 million Jordanian dinars in 2017 (see Figure 3).

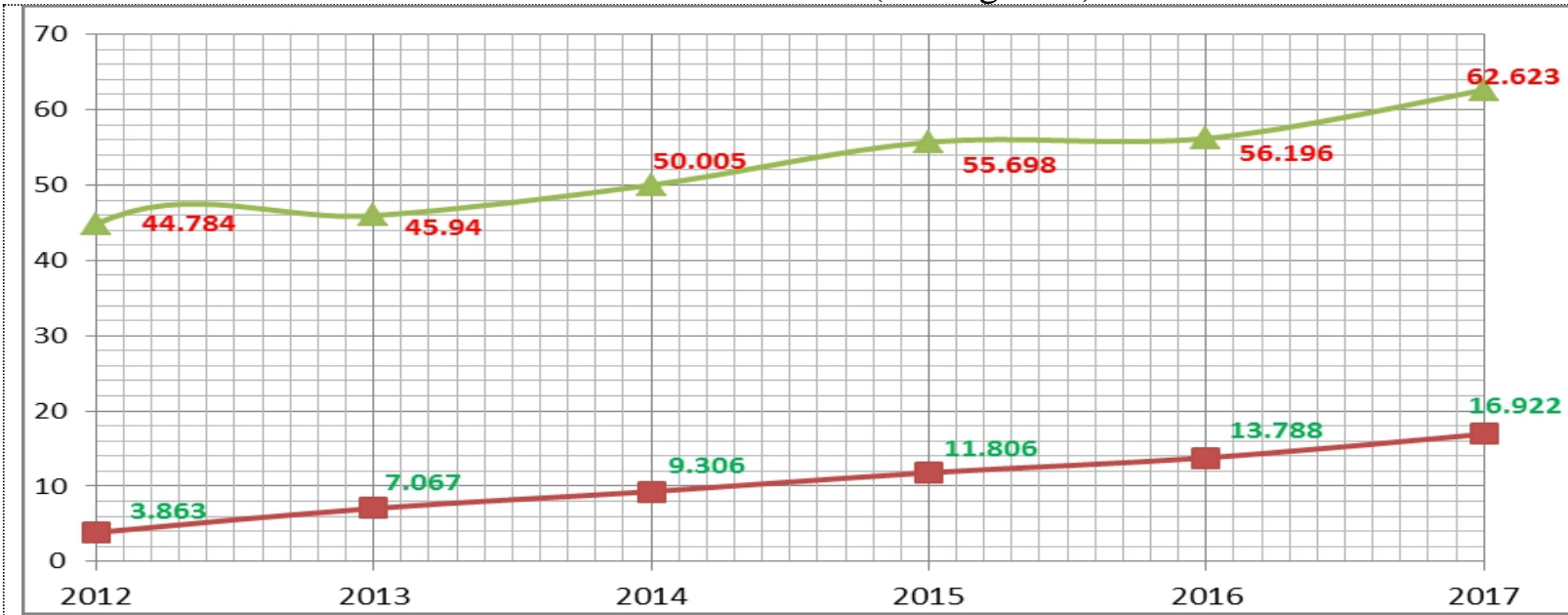

Figure 3. Comparisons between the total contributions and payments to/from the UIF

On one hand, the ratio of the unemployed insured persons reached $24.8 \%$ with monthly wages of less than 300 Jordanian dinars from the entire unemployed insured persons. On the other hand, the percentage of monthly 
wages for the category $301-600$ Jordanian dinars reached $43.9 \%$, and the monthly wages of those that exceed 600 Jordanian dinars reached $31.3 \%$.

The average amount of the total compensation that is paid from the UIF to beneficiaries reached 913 Jordanian dinars in 2012, increased to 1,102 Jordanian dinars in 2015, and reached 1234 Jordanian dinars in 2017. The estimation of the weighted average amount of the total compensation for every unemployed insured person reached 1059 Jordanian dinars during the period 2012-2017 (see Figure 4).

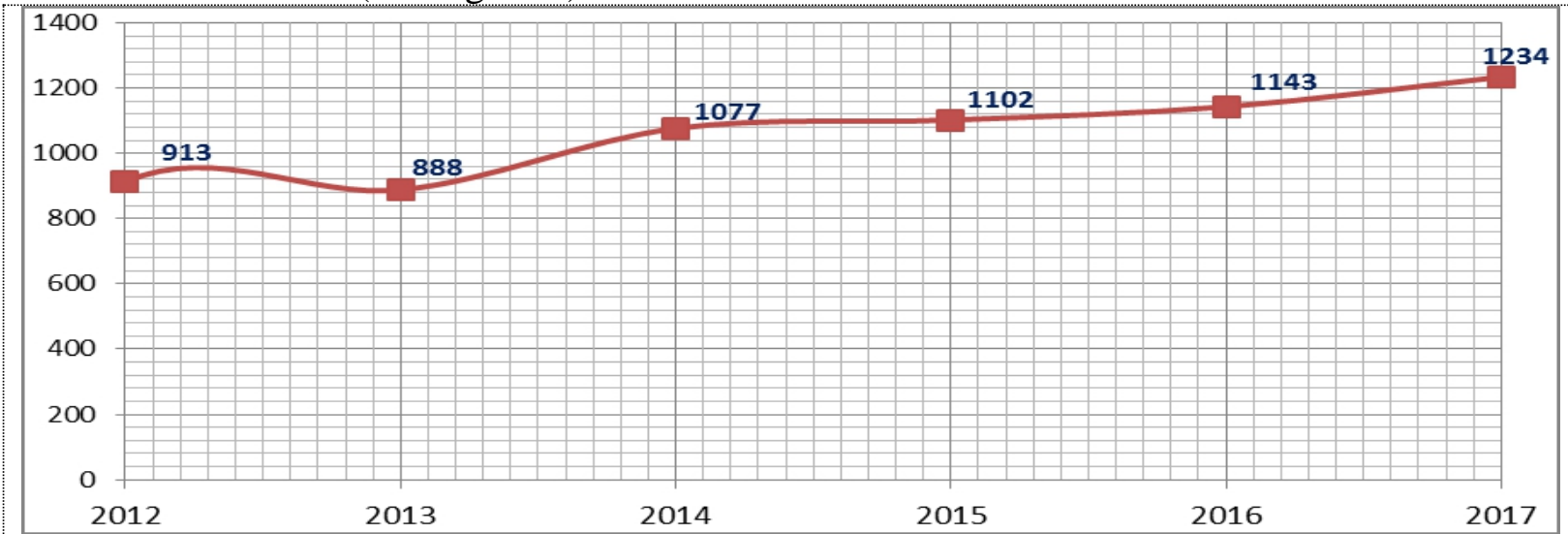

Figure 4 . The average of the total compensation that is paid by the UIF to beneficiaries during the period 20122017

Consequently, the weighted average of months that is compensated for the entire beneficiaries by the UIF results to 2.4 Months. Additionally, the estimation shows that $53.6 \%$ of beneficiaries gain three months of compensations, $19.8 \%$ gain two months of compensation, and $22.1 \%$ gain one month of compensation (see Figure 5).

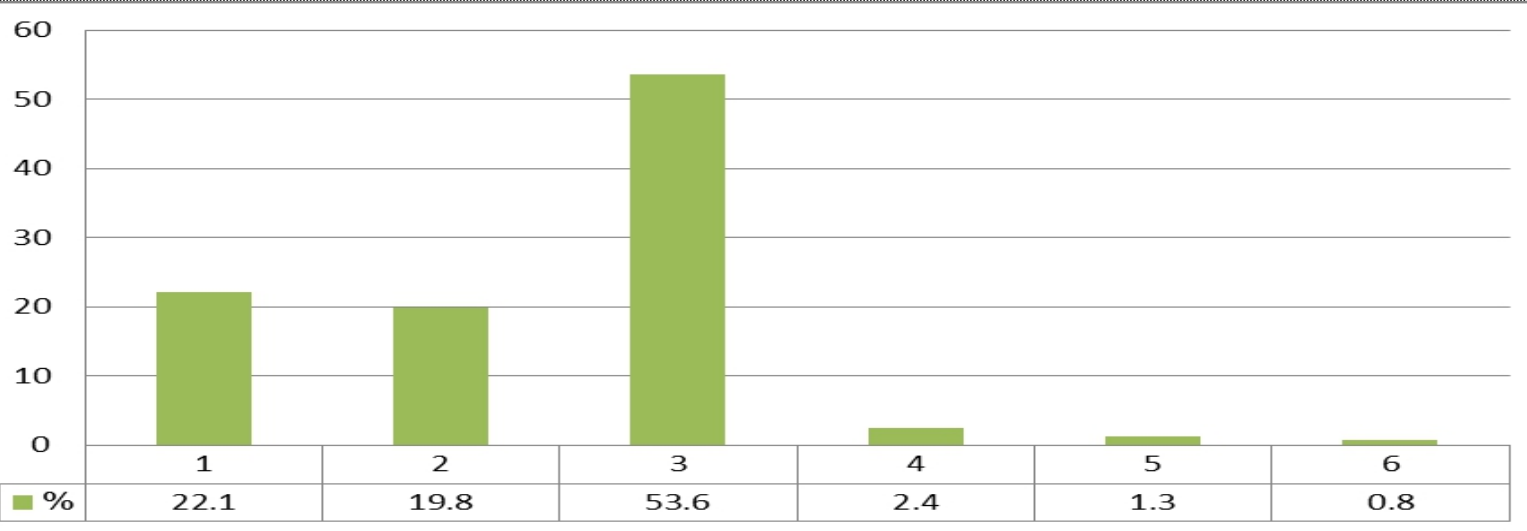

Figure 5. The percentage distribution of the number of months that are compensated for unemployed insured persons from the UIF during the period 2012-2017 
The weighted average of ages for the entire beneficiaries from the UIF is estimated by 37.3 years where $66.3 \%$ are aged at category $21-40$ years, while the remaining $33.7 \%$ represent their ages for more than 40 years. The estimation indicates that $90 \%$ of beneficiaries represent residents of four governorates distributed by $68.5 \%$ in Amman, $11.1 \%$ in Zarqa, $7 \%$ in Irbid, and $3.3 \%$ in Aqaba. The remaining ratio of beneficiaries is from Salt, Madaba, Ajloun, karak, and Jerash where no insured Jordanians are from both governorates (Tafeileh and Ma'an).

Meanwhile, the beneficiaries pertaining to their previous work represent $44.7 \%$ for two main economic activities, which are distributed by $23.9 \%$ from the manufacturing activity and $20.6 \%$ from the wholesale and retail trade activities. This is followed by $9.9 \%$ from the construction activity and $9.4 \%$ from the education activity (Social Security Corporation, 2017) (see Figure 6).

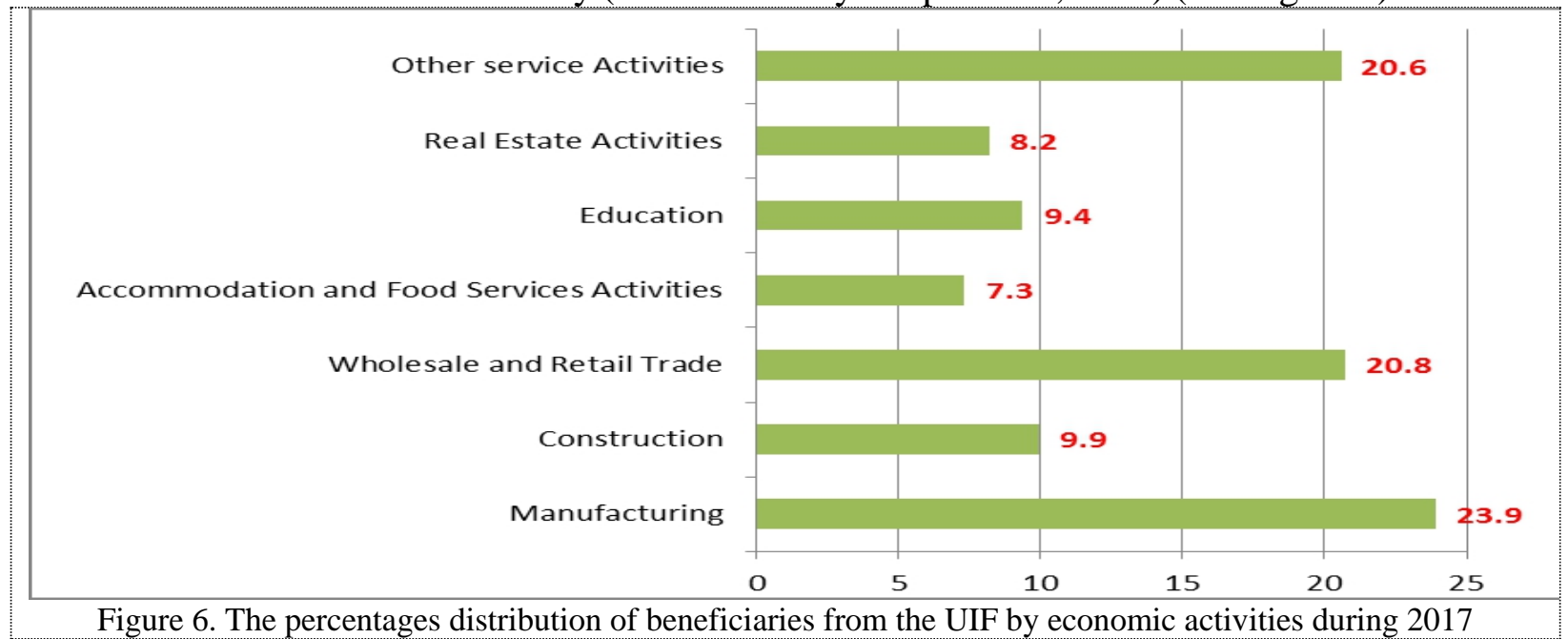

According to the above analysis, the UIF alleviates some negative impacts on the socio-economic of unemployed persons by improving their standard of living, achieving work stability, and rehabilitating their professional competencies in which the balance gap is reduced in the equilibrium of the local labour market. Furthermore, the positive impact of the UIF related to the national economy can be accomplished through increasing the GDI that is aimed at decreasing the socio-economic deprivation and poverty problem among unemployed Jordanians, particularly, within a low level income.

\section{- Benefits of Unemployment Insurance Fund}

The main results show that the UIF helps unemployed Jordanians who lost their jobs to obtain a sufficient income to continue to meet their daily needs. Hence, this would help to achieve the following positive impacts: 


\section{Alleviate Unemployment Impacts}

The UIF compensated 57325 unemployed persons during the period 2011-2017 by paying 62.623 million Jordanian dinars. This is with a weighted average amount that is paid to every unemployed Jordanian with 1059 Jordanian dinars. Accordingly, the compensations that are paid by the unemployment insurance fund for the entire beneficiaries alleviate the negative impacts on the socio-economic status of unemployed Jordanians.

\section{Improve the Standard of Living}

The UIF contributes to achieving more social justice which is necessary to activate the role of insurance fund against unemployment. This is due to the absence of an official role that provides living requirements during unemployment period. Additionally, the UIF alleviates the negative effects on the living standards of unemployed Jordanians.

Furthermore, the UIF improves the living standards for the entire insured Jordanian workers when being retired from their previous jobs due to the monthly deductions from workers and employers. Such deductions is deposited into the account of the unemployment insurance fund, which is considered as a future saving for the entire retired Jordanian workers as to whether or not they gain particular benefits from the UIF. Moreover, the total revenues of the unemployment insurance fund are considered as an account credit for insured Jordanians who could possibly settle their entire rights related to the instructions of insurance fund. This settlement occurs when insured Jordanians reach the retirement age and leave their jobs according to the UIF's procedures law indicated above.

\section{Achieve a Work Stability}

The labour market in private sectors is characterised with job instability, particularly, in small-medium sized corporations due to the increase turnover rate of work and labour movement. Such an increase causes negative reactions, psychological stress, and unsecured life for Jordanian workers.

The lack of confidence in the work stability leads to an encounter of low level of productivity due to the low level of mastery and dedication to work. This action may force the management authority to take precautionary actions to face any changes resulting from worse reputation or additional burdens. Additionally, the action may lead to changes in recruitment, selection, and advertising policies and may recruit new workers or produce pious reactions.

\section{Rehabilitation of Professional Competencies}

The UIF contributes to diagnosing the unemployment problem in private sectors and to finding the suitable solution for such a problem. This 
solution could guide the labour ministry towards an effective approach that reduces the unemployment rate through rehabilitating unemployed persons by enhancing their professional competencies to be ready for accessing the labour market.

Additionally, the UIF coordinates with professional training and rehabilitation centres in order to identify the trainings and skills for unemployed persons and to implement an individual development and capacity building programs. The UIF plays a significant role in returning unemployed persons back to their previous jobs or gaining entry into any other open investing opportunities and any current jobs.

If workers are keen to work and develop their skills, they would not struggle moving from their current job to another job. The reason behind this is that these workers have already subscribed in the SSC, which continues to support them till they reach the retirement age.

\section{Reducing Equilibrium Gap Between Supply and Demand in}

\section{Labour Market}

The UIF assists planners and economists to adopt significant labour market policies and to achieve a balance between supplying services by workers and the demand of workers by employers in local labour markets. Therefore, the UIF plays an effective role in reducing the balance gap between both sides, which was extremely a major issue over the past few years. This is due to the increment of unemployment rate that reached $18.7 \%$ in the Jordanian labour market (Department of Statistics, 2018).

\section{Positive Impacts of the UIF on Economy can be achieved through;}

- Increasing the Gross Domestic Income (GDI) as a result of the provision of a monthly compensation for unemployed insured Jordanians and to increase the per capita income for every individual.

- Increasing the employment rate in the Jordanian labour force.

- Increasing the future savings of unemployed insured persons that contribute for a long period in order to finance local investments and projects.

- Reducing the socio-economic deprivation and poverty problems of Jordanians resulting to a low level income.

- Ensuring the continuity of social security when leaving the labour market with a suitable level of their previous incomes.

- Operating the capital surplus of the UIF through economic projects and investments that would generate additional revenues for workers, which will in turn positively affect the growth rate of many economics. 


\section{Conclusion and Recommendations}

It was found that from the estimated results, increasing the percentages of insured persons refer back to the continuity of increasing unemployment rates at different educational levels. This increment is a mismatch between the qualification acquired by individuals and the type of qualifications required by the firms on demand. If this trend continues, it will lead to wastage of resources that are spent on building manpower.

Therefore, the government and the stake holders should take the correct or preventive measures when providing the curriculum and trainings, which align with the local labour market's needs through policy interventions. For instance, sending effective messages to students at secondary schools and also to their parents about the educational and technical specialisations is considered the most relevant and required jobs within the labour market in Jordan. On the contrary, the unemployment insurance fund ought to cover the entire firms that contribute to economic activities, including self-employed and typical workers. Four categories of benefits are covered under the unemployment insurance fund, namely; unemployment, maternity, illness, and relatives. This is dependent on the event of the contributor's death. In particular, these benefits are for those who remain covered with any other insurance programs.

Jordan has a large number of enterprises at small and micro levels in which staff members have to feel safer than ever. This policy encourages unemployed persons to engage in different job opportunities that are created by private sectors. The role of the unemployment insurance fund is to improve the effectiveness of the labour market mechanism. This role ensures that insured persons may get divers benefits particularly during the unemployment period by providing a suitable income that can secure their living conditions instead of entering chronic unemployment (Marcus Hagedorny et al., 2013). According to the results of the analysis and benefits of the UIF, the main suitable procedures and policies that are taken into consideration comprises of the following:

1) Extending the number of beneficiaries from the UIF in order to include unemployed persons with their monthly subscriptions in the SSC by exceeding more than 24 months instead of 36 months. The reason behind this is that the majority of unemployed persons are youths and are new entrants into the labour market.

2) The necessity to increase the value of the monthly compensation with a fixed ratio that is not less than $80 \%$ of the average monthly wage for the last 6 months should be more similar with the current monthly wage of insured persons. 
3) The unemployment insurance fund has to play many positive roles for the Jordanian workforce by implementing the following social-economic aspects:

- Providing protection to insured persons who leave the labour market on a temporary basis.

- Continuing to cover insured persons on the social security during the period of unemployment.

- Providing an adequate income to the insured persons for a limited period that meets their living requirements during the period of unemployment.

- Saving and investing in monthly deductions of the unemployment insurance fund for insured persons, which are returned to them when they are settled with the SSC.

- Enabling unemployed persons to improve their qualifications and abilities by attending training centres, which enhance them to obtain more suitable job opportunities.

- Continuing the cycle of income and expenditure, in contribution to the economic activity, which reduces the negative effects of the economic changes.

4) Reconsidering the article that denotes "it is not possible to combine compensation for insured unemployment and compensation for one payment in accordance with the article 68 of the Jordanian Labour Law, which guarantees only one payment for three months salary for the worker who is dismissed from his work using a forced method by the employer".

5) Reconsidering the exceptions that are included in providing the unemployment insurance law to maintain the rights of the workers that are expressly provided for workers as follows:

- It is not permissible to combine an unemployment allowance with the maternity leave allowance when the maximum allowance is paid.

- It is not permissible to combine an unemployment allowance with the compensation of one payment made in accordance with the provisions of Article (70) pertaining to this Law. If this compensation is due, the procedures stipulated in Article 57 of this Law shall be followed.

- It is not permissible to combine unemployment allowance with any pension or disability pension that is allocated in accordance with the provisions of this law.

6) Coordinating the efforts of international, regional, and local organisations that focus on the reduction of unemployment rate to develop the unemployment insurance fund. This is done to include further segments of unemployed persons, particularly, for young 
people, extending the period of the social insurance coverage, and finding new supporting resources.

7) Holding dialogue sessions at the national level between the representatives of insurance social partners, such as the Ministry of Labour, the Social Security Corporation, employers' associations, trading unions and labour unions, etc. This actions aims at discussing the mechanism of applying unemployment insurance law and its conditions of benefiting from it. The objectives of the insurance fund against leaving a job when reaching a unified formula includes the following:

- Providing social and economic protection in positive and concrete manners in order to improve the standard of living for unemployed persons.

- Achieving job stability and reducing work turnover, particularly, within the Jordanian labours.

- Reducing the negative effects of social, economic, behavioural, and psychological unemployment on unemployed Jordanians.

- Defining the professional competences gap of unemployed insured persons and enabling them to obtain appropriate jobs after being engaged in training programs. This will in turn rehabilitate their skills to meet up with the satisfaction level of employers.

- Encouraging fresh graduates to step forward towards existing jobs within private sectors since the unemployment insurance fund covers the insurance services for all workers in private sectors. In fact, this action leads to increase in the number of job seekers who are looking for existing vacancies within private sectors rather than only seeking jobs within the public sectors. Additionally, the change on the views of job seekers toward more than 300,000 jobs is occupied by non-Jordanian workers.

- Identifying the causes of challenges that employers and workers are faced with in a bid to overcome obstacles, which prevent the continuity of workers in their involved jobs.

- Activating the process of coordination, guidance, and exchange of views with many different training and rehabilitation centres. This is done in order to discuss and suggest useful training programs for unemployed insured persons that may help and serve as many employees and employers as possible.

- Achieving more justice and transparency for Jordanian workers in the local labour market in order to reduce the socio-economic burdens. 
- Increasing the usage level of human resources by reducing the rate of leaving the work as much as possible.

\section{Acknowledgements}

This paper has benefited from reports, studies, and regulations that have been issued and prepared by the SSC.

\section{References:}

1. Anna, G. \& Knut, R. (2014). 'Unemployment Insurance and Underemployment', Institute for the Study of Labor, Discussion Paper No, 7913.

2. Bennmarker, H., Carling, K., \& Holmlund, B. (2005). Do Benefit Hikes Damage Job Finding? Evidence from Swedish Unemployment Insurance Reforms', Department of Economics, Uppsala University, workings paper: ISSN 0284-2904, Available at:https://www.divaportal.org/smash/get/diva2:107255/FULLTEXT01.pdf.

3. Camille, L. et al., (2017). 'Risk-based Selection in Unemployment Insurance: Evidence and Implications', Economic \& Social Research Council, Institute for fiscal Studies. IFS working paper W17/22, Available at: https://www.ifs.org.uk/uploads/WP201722.pdf.

4. Camille, L., Pascal, M., \& Emmanuel, S. (2010). 'A macroeconomic Theory of Optimal Unemployment Insurance', National Bureau of Economic Research', Cambridge, MA 02138, working paper 16526, Available at: https://www.nber.org/papers/w16526.pdf

5. Christopher, O. \& Stephen, W. (1997). 'Unemployment Insurance in the United States Analysis of Policy', W.E. Upjohn Institute for Employment research, Michigan, USA. ISBN 0-88099-174-7, Available https://research.upjohn.org/cgi/viewcontent.cgi?article=1194\&contex $\mathrm{t}=$ up_press.

6. Coles, M. \& Masters, A. (2007). 'Re-entitlement Effects with Duration Dependent Unemployment Insurance in a Stochastic Matching Equilibrium', Journal of Economic Dynamics \& Control, Volume 31, Issue 9, pp 2879-2898, Available at: https://doi.org/10.1016/j.jedc.2006.09.011

7. Department of Statistics (2018). Second Quarterly Report. Amman, Jordan.

8. Department of Statistics, (2018). Labor and Unemployment Survey, First Quarter Report . Amman, Jordan.

9. James, C. \& Michael, R. (2006). 'Business Cycles, Unemployment Insurance, and the Calibration of Matching Models', Department of 
Economics and Business, Universitat Pompeu Fabra, Available at: https://econ-papers.upf.edu/papers/872.pdf

10. Julie, W. \& Katelin, I. (2017). Unemployment Insurance:Legislative Issues in the 115th Congress, Congressional Research Service, Cornell University ILR School, Federal publication, Available at: https://www.google.jo/\&httpsredir=1\&article=2947\&context=key_w orkplace.

11. Marcus, H. et al. (2013). 'Unemployment Benefits and Unemployment in the Great Recession: The Role of Macro Effects', Federal Reserve Banks of New York Staff reports. Available at: https://www.newyorkfed.org/medialibrary/media/research/staff_repor ts/sr646.pdf

12. Maria, E. (2012). 'Disadvantaged Workers and the unemployment insurance Program', Unemployment and Recovery Project, URBAN Institute. Www.urban.org, Available at: https://www.urban.org/research/publication/disadvantaged-workersand-unemployment-insurance-program.

13. Martin, N. (1978). 'Some Aspect of optimal Unemployment Insurance', Journal of Public Economics, North-Holland Publishing Company. Volume 10, Issue 3, pp379-402, Available at:https://www.sciencedirect.com/sdfe/pdf/download/eid/1-s2.00047272778900531/first-page-pdf.

14. Mathias, D. et al. (2014). 'An Unemployment Insurance Scheme for the Euro Area? A Comparison of Different Alternatives using Micro Data', Centre for European Economic Research, ZEW. Discussion Paper No. 14-095, Available at:http://ftp.zew.de/pub/zewdocs/dp/dp14095.pdf

15. Ministry of Labour (2017). Jordanian Labour market in Numbers 2012-2016. The policies and international cooperation department. Amman, Jordan.

16. Ministry of Labour (2018). The National Labour Market Indicators 2013-2017. Policies and International cooperation Directorate, labour Market Information Department. Amman, Jordan.

17. Monica, T. \& Kevin, H. (2007). Women and the Unemployment Insurance Program, Canadian Centre for Policy Alternatives, ISBN (978-0-88627-569-3), Toronto, Ontario. Available at: http://www.policyalternatives.ca/sites/default/files/uploads/publicatio ns/National_Office_Pubs/2007/Women_and the EI_Program.pdf

18. Rafael, T. \& Robert, C. (2002). 'The Determination of Unemployment Benefits', Journal of Labor Economics, Vol.20, No.2, University of Chicago, Available at: https://www.journals.uchicago.edu/doi/pdfplus/10.1086/338690 
19. Service Canada (2010). Employment Insurance Regular Benefits. Available at: https://www.canada.ca/en/employment-socialdevelopment/corporate/portfolio/service-canada.html

20. Social Security Corporation (2016). Annual Report. Amman, Jordan, www.ssc.gov.jo.

21. Social Security Corporation (2017). Annual Report. Amman, Jordan, www.ssc.gov.jo.

22. Social Security Corporation (2018). Annual Report. Amman, Jordan, www.ssc.gov.jo.

23. Social Security Corporation: Social Security law (No1 for 2014). Amman, Jordan.

24. Sondos, J. \& Kharmeh, S. (2010). 'The Jordanian Workers' Remittances Impact on the Main Macroeconomic Variables', International Research Journal of Finance and Economics. ISSN 1450-2887 Issue 41. pp121-135.

25. The Council of Economic Advisers and the Department of Labor (2013). The Economic Benefits of Extending Unemployment Insurance. Executive office of the president of the USA. Available at: https://obamawhitehouse.archives.gov/sites/default/files/docs/uireport -2013-12-4.pdf

26. The Hashemite Kingdom of Jordan (2014). 'Insurance of unemployment, the Insurance Benefits of the Public Institution for Social Security', The Official Newspaper No. 5329, under Article 31 of the Constitution, Law No. 15, Chapter Five:. Issued under Article 106 of the Social Security Law No. (1).

27. The Legal Aid Society Employment Law Center (2010). A Guide for Advocates- Unemployment Insurance Benefits in California, Available at:fvalle-miller@las-elc.org

28. Vroman, W. \& Brusentsev,V. (2005). Unemployment Compensation throughout the World A Comparative Analysis, W.E. Upjohn Institute for Employment Research Kalamazoo, Michigan,chapter1, pp 1-6, Available at: https://doi.org/10.17848/9781417596355

29. Yasuhiro, K. (2010). 'Employment Structure and Unemployment Insurance in East Asia: A Strategy to Establish Social Protection for All Workers', Japan National Committee for Pacific Economic Cooperation (ed.), Report of the Social Resilience Project, pp153-170, Available at: https://www.mhlw.go.jp/topics/2011/03/dl/h10.pdf 